\title{
OPEN SOURCE SEBAGAI ALTERNATIF \\ PENGURANGAN PELANGGARAN HAK CIPTA \\ PROGRAM KOMPUTER DI INDONESIA
}

\author{
Nuzulia Kumala Sari, Budi Santoso
}

\begin{abstract}
ABSTRAK
Hak Milik Intelektual telah mencakup hampir seluruh fase kehidupan, mulai dari hak cipta, paten, merek, desain industri, desain tata letak sirkuit terpadu, rahasia dagang dan bahkan varietas tanaman.

Program komputer sebagai hasil pemikiran intelektual dari pembuat program atau pencipta diakui sebagai suatu Karya Cipta, yaitu karya dari perwujudan cipta, rasa dan karsa nya yang dilindungi dengan hak cipta. Perlindungan yang diberikan oleh Undang-Undang terhadap hak cipta program komputer adalah untuk merangsang aktivitas dan kreatifitas agar para pencipta memiliki gairah dan semangat untuk melahirkan karya cipta.

Pelanggaran Hak Cipta di bidang program komputer pada saat ini marak terjadi di Indonesia. Menurut laporan Business Software Alliance (BSA) yang dituangkan dalam global software piracy 1997, Indonesia sebagai negara ketiga yang melakukan pembajakan terbesar, yakni 93\% setelah Vietnam (99\%) dan China (96\%). Pada 2005 sekira $87 \%$ perangkat lunak yang ada di Indonesia adalah produk bajakan. Angka ini stabil sama persis seperti tahun 2004 dan turun satu digit dari tahun 2003 yang menorehkan "hasil" 88 persen. Indonesia di mata Amerika dianggap sebagai negara yang paling lemah dalam penegakan hukum (Law Enforcement) di bidang pelanggaran pembajakan program komputer. Berdasarkan pengamatan UTR (United Trade Representative) Indonesia berada dalam kelompok negara Priority Watch list, yaitu daftar negara yang dianggap perlu diawasi karena penegakan hukumnya di anggap lemah terhadap pelanggaran Hak Milik Intelektual, dan menobatkan Indonesia sebagai nomor tiga dalam daftar "20 Country with the Highest Piracy Rates". Tepat di di bawah Vietnam dan Zimbabwe. Pada Tahun 2006 muncul laporan terbaru tentang tingkat pembajakan perangkat lunak (software). Dikarenakan tingginya pelanggaran hak cipta program komputer di Indonesia maka di harapakan open source sebagai alternatif pengurangan pelanggaran hak cipta di Indonesia.

Penelitian ini bermaksud memperoleh kejelasan masalah: (a) pelanggaran hak cipta program komputer di Indonesia; (b) perlindungan hak cipta program komputer dalam UU Hak Cipta di Indonesia; (c) Open Source sebagai alternatif mengurangi tingkat pelanggaran hak cipta program komputer di Indonesia.

Metode pendekatan yang digunakan dalam penelitian ini adalah metode pendekatan yuridis-normatif yaitu melihat hukum dalam perspektif hukum positif
\end{abstract}


atau hukum di konsep kan sebagai norma-norma positif di dalam sistem perundangundangan. Dalam pendekatan ini lebih jauh melihat substansi, asas, doktrin, maupun peraturan dalam hukum positif mengenai hak cipta. Spesifikasi penelitian bersifat deskriptif analitis dengan menggunakan metode pengumpulan data Sekunder yang dilakukan melalui studi kepustakaan atau teknik dokumentasi.

Hasil penelitian sementara menunjukkan bahwa: (a) pelanggaran hak cipta program komputer dilakukan dengan lima kategori yaitu Pemuatan hard disk (Hard Disk Loading), Soft lifting, Pemalsuan perangkat lunak (Software Counterfeiting), Penyewaan perangkat lunak, dan Downloading Illegal melalui Internet. (b) Di Indonesia, program komputer termasuk dalam salah satu karya yang dilindungi dengan hak cipta. Dalam UU No.6 tahun 1982 tentang Hak Cipta, program komputer belum termasuk karya cipta yang dilindungi hak cipta. Baru dengan UU No. 7 tahun

1987 tentang perubahan UU No. 6 tahun 1982 tentang Hak Cipta maka program komputer dimasukkan sebagai bagian dari karya cipta yang dilindungi dengan hak cipta di Indonesia. Perkembangan selanjutnya adalah juga dimasukkannya program komputer yang dilindungi hak cipta pada UU No.12 tahun 1997. Terakhir dengan UU No. 19 tahun 2002 tentang Hak Cipta, program komputer itu sendiri diatur pada pasal

12 UUHC yang menyatakan bahwa program komputer merupakan salah satu bentuk ciptaan yang dilindungi. (c) Indonesia saat ini mulai disadari akan keterbatasan ketersediaan dana untuk pembelian perangkat lunak, maka dengan menggunakan open source hak ekonomi dari pemegang Hak Cipta telah dilepas dari semula, sehingga setiap pengguna dapat dengan bebas untuk memperbanyak, mendistribusikan ulang, menyewakan bahkan merubah atau menambah Source Code dari suatu program, jadi biaya lisensi dapat dikatakan menjadi nol rupiah. Hal ini merupakan suatu terobosan cemerlang khususnya untuk kondisi Indonesia saat ini tingginya tingkat pelanggaran hak cipta program komputer.

Atas dasar penelitian tersebut, direkomendasikan: (a) sosialisasi terhadap penggunaan software open source yang relatif masih baru ini sehingga masyarakat pengguna software dapat mengetahui adanya software alternatif yang aman digunakan dan mudah untuk dioperasikan. Aman artinya software yang digunakan tersebut tidak melanggar hukum dan mudah dioperasikan artinya pengoperasiannya tidak jauh berbeda dengan sistem operasi yang sekarang ada; (b) penggunaan software open source dapat dioptimalkan pemanfaatannya karena berbagai potensi dan keunggulan yang dimilikinya, sehingga dapat digunakan dalam berbagai bidang. Pemanfaatan ini misalnya di bidang pendidikan yang umumnya kekurangan biaya untuk membeli infrastruktur yang berkaitan dengan teknologi.

\section{Kata Kunci: Hak Cipta, Pelanggaran Hak Cipta Program Komputer, Open Source}




\section{A. PENDAHULUAN}

\section{A.1. Latar Belakang}

Keberadaan Hak Milik Intelektual (HMI) dalam hubungannya antar manusia dan antar negara merupakan sesuatu yang tidak dapat dipungkiri lagi. Keberadaannya senantiasa mengikuti dinamika perkembangan masyarakat itu sendiri. Begitu pula halnya dengan masyarakat dan bangsa Indonesia yang mau tidak mau bersinggungan dan terlibat langsung dengan masalah HMI.

Hak Milik Intelektual (HMI) merupakan hasil proses kemampuan berpikir manusia yang di wujudkan ke dalam suatu bentuk ciptaan atau penemuan. HMI dapat diartikan sebagai hak milik terhadap karya-karya yang timbul atau lahir karena adanya kemampuan intelektualitas manusia dalam bidang ilmu pengetahuan dan teknologi. Karya-karya tersebut merupakan kebendaan tidak terwujud yang merupakan hasil kemampuan intelektualitas seseorang atau manusia dalam bidang ilmu pengetahuan dan teknologi melalui daya cipta, rasa, karsa dan karyanya yang memiliki nilai-nilai moral, Praktis dan ekonomis. Pada dasarnya yang termasuk dalam lingkup HMI adalah segala karya dalam bidang ilmu pengetahuan dan teknologi yang dihasilkan melalui akal atau daya pikir seseorang atau manusia tadi. Hal inilah yang membedakan HMI dengan hak-hak milik lainnya yang diperoleh dari alam. ${ }^{1}$

HMI telah mencakup hampir seluruh fase kehidupan, mulai dari hak cipta, paten, merek, desain industri, desain tata letak sirkuit terpadu, rahasia dagang dan

1 Bambang, Kesowo, Pengantar Umum Mengenai Hak Atas Kekayaan Intelektual (HAKI) di Indonesia. Makalah yang disajikan pada Penataran Dosen Hukum Dagang se-Indonesia, (Yogyakarta: Fakultas Hukum Universitas Gadjah Mada, 1995), hal. 5. 
bahkan varietas tanaman. Dari sudut produk, HMI akan berurusan dengan berbagai kepentingan manusia, dari pengetahuan tradisional seperti pengelolaan jamu dan perlindungan folklore sampai ke bisnis internet untuk menampung kebutuhan dari ekonomi digital saat ini.

HMI yang telah mempunyai cakupan yang luas menyebabkan munculnya pandangan dan ide melontarkan anti copyright, sebagai akibat begitu banyaknya pembatasan hak milik intelektual, terutama hak cipta dan paten, telah menimbulkan semacam gerakan untuk kembali ke Intellectual Freedom sebagai lawan intellectual property right.

Kita memang patut merenungkan sebuah tulisan seorang professor tentang penjelasan hak cipta sebagai berikut:

"The newspaper you read this morning, the television show you watched last night, the movie you are going to see this week end, the computer software you use to prepare your letters or send e-mail, the music you listen in the car on your way to work: they are all copyrighted. Copyright permeates our lives...."

Ditambahkan bahwa:

"For many people outside America (and many inside), materials aren't distributed because of copyright laws, so it might be more relevant to explain copyright this way The newspaper you couldn't get this morning, the television show you couldn't get last night, the movie you can't see this weekend, the computer software you can't use to prepare your letters or send your e-mail, the music you can't listen in the car on your way to work: they are all copyrighted. Copyright permeates your life...".

Pandangan-pandangan baru mulai bermunculan mengkritik komersialisasi hak cipta secara berlebihan, terutama datang dari para pemikir hak cipta di Amerika Serikat. Richard Stallman, dalam artikelnya menyebutkan bahwa para pendahulu di Amerika Serikat telah mengambil premise yang berbeda mengenai hak cipta, bahwa hak cipta bukan hak alamiah yang diperoleh si pencipta, tetapi

${ }^{2}$ Ibid. 
merupakan konsesi yang diberikan pada mereka oleh konstitusi demi sebuah kemajuan. $^{3}$

Richard Stallman juga dikenal sebagai tokoh gerakan anti copyright, khususnya di bidang software komputer, yang dikenal dengan copyleft. Copyleft tidak bertujuan agar suatu karya cipta tersebut sebagai milik pribadi, tetapi justru menginginkan agar karya cipta tersebut, yang berbentuk perangkat lunak, berposisi tetap bebas (free software). Contoh free software license yang kuat menggunakan copyleft adalah GNU (GNU is Not Unix) General Public Licensel GNU GPL, dan $Q$ Public License.

Acuan yang dijadikan dasar bekerjanya copyleft adalah:

a. use it without limitation;

b. (re) distribute it in as any copies es as desired, and

c. modify it in any way they see fit. ${ }^{4}$

Pada umumnya para pengembang program komputer menggunakan hak cipta untuk membatasi kebebasan pengguna program, tetapi copyleft menggunakan hak cipta untuk menjamin kebebasan para penggunanya, itulah sebabnya mengapa istilah copyright diplesetkan menjadi copyleft. Penggunaan free software dalam copyleft dapat digandakan tanpa perlu izin khusus dari penciptanya atau pemegang hak cipta dan itu bukanlah pelanggaran hak cipta. Namun yang perlu diperhatikan penggunaan free software tersebut harus patuh pada aturan General Public License (GPL) yang menghendaki setiap pendistribusian ulang perangkat lunak berstatus copyleft haruslah tetap bebas. Dengan demikian GPL tetap menggunakan mekanisme perlindungan hukum berupa hak cipta serta menggunakan mekanisme lisensi dalam penyebarluasan

\footnotetext{
${ }^{3}$ Budi, Santoso, Dekonstruksi Hak Cipta, Studi Evaluasi Konsep Pengakuan Hak dalam Hak Cipta di Indonesia, Disertasi, (Semarang: Program Doktor Ilmu Hukum, Universitas Diponegoro, 2006), hal. 404.

${ }^{4}$ Ibid.
} 
nya. Model ini sangat membantu pengguna yang tidak mempunyai kemampuan finansial yang cukup untuk membeli lisensi perangkat lunak yang ber-copyright. GPL menggunakan pemanfaatan open source sebagai perangkat lunak yang bebas digunakan, beberapa open source yang popular adalah LINUX, Mozilla Firefox, the Apache Web Server.

Di Indonesia mahalnya harga software original memang merupakan alasan klasik menjamurnya penggunaan perangkat lunak yang illegal. Untuk menjalankan komputer rakitan seharga Rp. 3 Jutaan dibutuhkan dana untuk software dasar seharga AS \$248, atau sekitar Rp. 2, 4 Juta, dengan perincian untuk Windows XP Home AS \$ 78 dan MS Office 2003 Basic AS \$ 170, belum termasuk program yang lain. ${ }^{5}$

Menurut laporan Business Software Alliance (BSA) yang dituangkan dalam global software piracy 1997, Indonesia menempati sebagai negara ketiga yang melakukan pembajakan terbesar, yakni 93\% setelah Vietnam (99\%) dan China (96\%). Pada Tahun 2006 muncul laporan terbaru tentang tingkat pembajakan perangkat lunak (software) di dunia dan menobatkan Indonesia sebagai nomor tiga dalam daftar " 20 Country with the Highest Piracy Rates". Tepat di di bawah Vietnam dan Zimbabwe. Laporan yang dilansir lembaga riset IDC dan BSA (Aliansi Industri Perangkat Lunak). ${ }^{6}$

Meski secara formal usaha mengurangi pembajakan ini telah banyak dilakukan melalui berbagai regulasi dan bahkan MUI-pun telah mengeluarkan fatwa haram menggunakan perangkat lunak bajakan sejak tahun 2003, faktanya prestasi bangsa Indonesia tetap tak beranjak dari lima besar pembajak software di dunia.

Mahalnya harga software original inilah yang menjadikan alasan banyaknya Warnet menggunakan perangkat lunak bajakan agar dapat memberikan harga

\footnotetext{
${ }^{5}$ Budi, Santoso, Tren Pandangan Terhadap Hak Cipta, (Semarang: Majalah Masalah-Masalah Hukum FH UNDIP, Vol. 34 No. 2 April - Juni 2006), hal. 408.

${ }^{6}$ www. kcm.com., Kompas Cyber Media, Pembajakan Software Memprihatinkan, 2007.
} 
sewa yang competitive di pasar. Tetapi, hal itu pulalah yang menjadikan pengusaha warnet merasa resah pada saat aparat POLRI melakukan sweeping software bajakan, khususnya untuk XP dan Windows Me. Beralih ke software orisinil tentunya membutuhkan investasi yang tidak sedikit serta tidak adanya jaminan uang tersebut akan kembali. Salah satu alternatifnya adalah beralih ke program lain yang bersifat open source.

Open Source memiliki kelebihan yaitu ini dengan tidak mengikuti ketentuan copyright pada umumnya karena hak ekonomi dari pemegang Hak Cipta telah dilepas dari semula, sehingga setiap pengguna dapat dengan bebas untuk memperbanyak, mendistribusikan ulang, menyewakan bahkan merubah atau menambah Source Code dari suatu program. Hal tersebut dimungkinkan karena terhadap program dengan basis Close Source menerapkan model lisensi yang lain, yang sering disebut dengan istilah lisensi Close Source. Salah satu lisensi dari Open Source tersebut adalah GNU is Not UNIX General Public License (GNU GPL) yang bertujuan untuk membatasi bagi developer yang memiliki lisensi menjadi produk komersial yang tidak memberikan kontribusi balik pada komunitas. GPL ini menggunakan copyright untuk menjamin agar program tetap free dibawah lisensi GNU GPL. Setiap orang boleh mengcopy, mendistribusikan dan memodifikasi namun harus disertai dengan lisensi GNU GPL juga yang tujuannya adalah mendistribusikan software-software yang bernaung dibawah lisensi ini secara gratis dan terbuka. Bagi pencipta program komputer yang melindungi ciptaannya dengan lisensi GNU GPL mendapat perlindungan terhadap ciptaannya dalam bentuk pencatuman nama dalam setiap perbanyakan, kutipan atau modifikasi dari program tersebut, oleh karena itu, Open Source tidak mengenal istilah pembajakan.

Indonesia sebagai negara sedang berkembang cocok untuk menggunakan software dengan lisensi Open Source ini karena bisa mengembangkan teknologi informasinya berbasis pada sumber daya manusia dan tidak sepeser uang dari dalam negara indonesia yang mengalir ke luar negeri. Dalam perkembangannya, 
ternyata program Open Source ini mendapat tanggapan positif dari pemerintah, terbukti pada tahun 2001 dikeluarkan Inpres no 2 dan no 6 tahun 2001 mengenai proyek pemerintah P2LBI dengan membuat distribusi dan dokumentasi Linux yang disediakan bebas untuk publik dan berbahasa Indonesia.

Berdasarkan berbagai kondisi yang telah di uraikan di atas, jelaslah bahwa Open Source merupakan alternatif pengurangan pelanggaran hak cipta program komputer di indonesia. Langkah selanjutnya adalah meneliti bagaimana Open Source dapat berkiprah sebagai pengganti perangkat lunak yang selama ini ada, hal inilah yang merupakan fokus dalam penelitian ini. Hal demikian merupakan topik yang cukup menarik untuk dikaji lebih mendalam melalui kegiatan penelitian seperti yang penulis laksanakan ini.

Melihat dari wacana diatas, dalam penelitian dengan judul "Open Source Sebagai Alternatif Pengurangan Pelanggaran Hak Cipta Program Komputer di Indonesia".

\section{A.2. Permasalahan}

Berdasarkan latar belakang di atas, maka dapat dirumuskan permasalahan sebagai berikut:

1. Bagaimana gejala pelanggaran hak cipta program komputer di Indonesia?.

2. Bagaimana perlindungan hak cipta program komputer dalam UU Hak Cipta di Indonesia?.

3. Apakah Open Source bisa dijadikan sebagai alternatif mengurangi tingkat pelanggaran hak cipta program komputer di Indonesia?.

\section{A.3. Tujuan Penelitian}

Adapun tujuan dari penelitian ini adalah sebagai berikut:

a. Untuk mengetahui gejala pelanggaran hak cipta program komputer di Indonesia. 
b. Untuk mengetahui perlindungan hak cipta program komputer dalam UU Hak Cipta di Indonesia.

c. Untuk mengetahui apakah Open Source bisa dijadikan sebagai alternatif mengurangi tingkat pelanggaran hak cipta program komputer di Indonesia.

\section{A.4. Tinjauan Pustaka}

Tinjauan pustaka yang saya sajikan pada kesempatan seminar hasil penelitian kali ini merupakan tinjauan pustaka yang ditulis secara ringkas, dikarenakan keterbatasan jumlah halaman yang dipersyaratkan dalam makalah seminar hasil penelitian ini.

Hak Milik Intelektual (HMI) ini merupakan hak yang berasal dari hasil kegiatan kreatif suatu kemampuan daya pikir manusia yang diekspresikan kepada khalayak umum dalam berbagai bentuknya, yang memiliki manfaat serta berguna dalam menunjang kehidupan manusia, juga mempunyai nilai ekonomi. Bentuk nyata dari kemampuan karya intelektual tersebut bisa di bidang teknologi, ilmu pengetahuan, maupun seni dan sastra.

Bouwman-Noor Mout menyatakan bahwa HMI merupakan hasil kegiatan berdaya cipta pikiran manusia yang diungkapkan ke dunia luar dalam suatu bentuk, baik material maupun immaterial. Bukan bentuk penjelmaan nya yang dilindungi, akan tetapi daya cipta itu sendiri. Daya cipta itu berwujud dalam bidang antara lain seni, industri dan ilmu pengetahuan atau ketiga-tiganya. ${ }^{7}$

HMI pada intinya terdiri dari beberapa jenis seperti yang digolongkan oleh WIPO (World Intellectual Property Organization), yaitu: ${ }^{8}$

\section{a. Hak Cipta (Copy Right);}

b. Hak Kekayaan Industri (Industrial Property), yang mencakup:

${ }^{7}$ Bouwman-Noor Mout, Perlindungan Hak Cipta Intelektual, Suatu Rintangan atau Dukungan Terhadap Perkembangan Industri, Makalah pada Seminar Hak Milik Intelektual, Kerjasama FH. USU dengan Naute van Haersolte Amsterdam, Medan Fakultas Hukum USU, tanggal 10 januari 1989, hal. 1.

${ }^{8}$ WIPO, Bab II bagian B1. 
1) Paten (Patent);

2) Merek (Trade Mark);

3) Desain Produk Industri; dan

4) Penanggulangan praktek persaingan curang (Repression of Unfair Competition Practices)

Sistematika IPR atau Hak Kekayaan Industri yang diikuti oleh WIPO yang berlaku sampai saat ini terdiri dari: ${ }^{9}$

(a) Paten Sederhana (Utility Model) dan Desain Produk Industri (Industrial Design);

(b) Merek, termasuk Merek Dagang (Trade Mark), Merek Jasa (Service Mark), Nama Perusahaan (Trade Name), Petunjuk Sumber (Indication of Source) dan Sebutan Asal (Appellation of Origin).

Menurut TRIPS (Trade Related Aspects of Intellectual Property Rights), pada Pasal 1 ayat 2 yang dimaksud dengan HMI adalah semua kategori kekayaan intelektual sebagaimana dimaksud dalam bagian 1 sampai dengan 7 Bab II Agreement TRIPS yang mencakup:

1. Hak Cipta dan Hak-hak terkait lain (Copyrights and Related Rights);

2. Merek Dagang (Trade Marks);

3. Indikasi Geografis (Geographical Indications);

4. Desain Produk Industri (Industrial Designs);

5. Paten (Patent);

6. Desain Lay Out (topografi) dari Rangkaian Elektronik Terpadu (Lay Out Designs (Topographies) of Integrated Circuits), perlindungan terhadap informasi yang dirahasiakan (Protection of Undisclosed Information).

\footnotetext{
${ }^{9}$ Article Paris Convention for The Protection of Industrial Property 1967.
} 
Menurut Bahasa Indonesia, istilah hak cipta berarti hak seseorang sebagai miliknya atas hasil penemuannya yang berupa tulisan, lukisan dan sebagainya yang dilindungi oleh undang-undang. Dalam bahasa Inggris disebut Copy Right yang berarti hak cipta. Adapun pengertian secara yuridis menurut UndangUndang RI Nomor 19 Tahun 2002 tentang Hak Cipta, dalam Pasal 1 yang dimaksud dengan Hak Cipta adalah hak eksklusif bagi pencipta atau penerima hak untuk mengumumkan atau memperbanyak ciptaannya atau memberikan izin untuk itu dengan tidak mengurangi pembatasan-pembatasan menurut peraturan perundang-undangan yang berlaku.

Definisi Open Source dalam Kamus Istilah Komputer dan Internet. Open Source adalah perintah-perintah program atau bahasa pemrograman yang tersedia secara gratis untuk digunakan oleh kalangan luas. Boleh dimodifikasi dan digunakan oleh siapa saja. ${ }^{10}$

Agar suatu program dapat dikategorikan sebagai program yang Open Source, maka program tersebut harus memenuhi syarat-syarat yang terdapat dalam definisi Open Source secara bersamaan dan pada semua keadaan. Definisi Open Source sendiri memiliki tujuan untuk melindungi proses Open Source dan menjamin perangkat lunak yang didistribusikan dengan menggunakan lisensi Open Source akan tersedia secara bebas dan dapat mengalami perbaikan terus menerus hingga dapat mencapai tingkat kehandalan serta menjaga kemungkinan menjadi produk yang Close Source. Istilah dari Open Source sendiri tidak sematamata hanya berarti adanya keterbukaan untuk mengakses Source Code perangkat lunak, namun sebenarnya memiliki cakupan arti yang lebih luas. Mengacu pada the Open Source definition version 1.3, maka Open Source adalah:

\section{a. Free Redistribution \\ b. Source Code}

${ }^{10}$ Luthfi F, Kamus Istilah Komputer dan Internet, (Yogyakarta: Pena Media, 2005), hal 174. 


\section{c. Derivad Works \\ d. Integrity of The Autor's Source Code \\ e. No Discrimination Against Persons or Groups \\ f. No Discrimination Against Fields of Endeavor \\ g. Distribution of License \\ h.License Must Not Be Spesific to a Product \\ i. License Must Not Contaminated Other Software \\ j. Conforming License and Sertification}

Penjelasan tentang bagaimana berbagai lisensi yang ada dalam masyarakat dapat dicocokkan dengan Open Source definition setelah melalui semacam uji oleh Open Source initiative, yaitu lembaga yang mewakili komunitas Open Source.

\section{A.5. Metode Penelitian}

\section{A.5.1. Metode Pendekatan}

Metode pendekatan yang digunakan dalam penelian ini adalah metode pendekatan yuridis-normatif yaitu melihat hukum dalam perspektif hukum positif atau hukum di konsep kan sebagai norma-norma positif di dalam sistem perundang-undangan. ${ }^{11}$ Dalam pendekatan ini lebih jauh melihat substansi, asas, doktrin, maupun peraturan dalam hukum positif mengenai hak cipta.

\section{A.5.2. Spesifikasi penelitian}

Spesifikasi penelitian dalam tesis ini bersifat deskriptif analitis. Yaitu suatu penelitian yang bertujuan untuk menggambarkan secara tepat sifat-sifat suatu individu, keadaan, gejala atau kelompok tertentu, atau yang menentukan penyebaran suatu gejala, atau untuk menentukan ada tidaknya hubungan

${ }^{11}$ Soerjono, Soekanto dan Sri, Mamudji, Penelitian Hukum Normatif, (Jakarta: PT Raja Grafindo Persada, 2004), hal. 12. 
antara suatu gejala dengan gejala lain dalam masyarakat. Kemudian dianalisa dengan menggunakan peraturan-peraturan hukum yang berlaku. ${ }^{12}$

\section{A.5.3. Data dan Sumber Data}

Metode pengumpulan data dalam penelitian ini menggunakan Data Sekunder, yaitu data yang telah diolah dan yang diperoleh secara tidak langsung. 13

Sumber data sekunder yang digunakan dalam penelitian ini mencakup:

a. Bahan hukum primer, yaitu bahan-bahan hukum yang mempunyai kekuatan mengikat seperti peraturan perundang-undangan atau putusan pengadilan. Bahan hukum yang digunakan dalam penelitian ini berupa peraturan perundang-undangan. Misalnya, Undang-Undang No. 19 Tahun 2002 tentang Hak Cipta

b. Bahan Hukum Sekunder, yaitu semua bahan hukum yang memberikan penjelasan terhadap bahan hukum primer. Misalnya, jurnal, website (Homepage atau situs) hak milik intelektual.

c. Bahan hukum tersier, yaitu semua bahan hukum yang memberikan petunjuk atau penjelasan terhadap bahan hukum primer dan sekunder. Misalnya, Kamus Besar Bahasa Indonesia, dan Kamus Bahasa Inggris.

\section{A.5.4 Metode Pengumpulan Data}

Metode pengumpulan data yang digunakan dalam penelitian ini adalah studi kepustakaan atau teknik dokumentasi.

\footnotetext{
12 Amiruddin dan Zainal, Asikin, Pengantar Metode Penelitian Hukum, (Jakarta: PT Raja Grafindo Persada, 2005), hal. 25.

13 Ibid.
} 


\section{A.5.5. Metode Pengolahan dan Analisis Data}

Metode analisis data yang dipergunakan adalah analisis data kualitatif, yaitu proses penyusunan, mengkategorikan data kualitatif, mencari pola atau tema dengan maksud memahami maknanya. Memusatkan perhatian pada prinsip-prinsip umum yang mendasari perwujudan satuan-satuan gejala yang ada dalam kehidupan manusia, atau pola-pola yang dianalisis gejala-gejala sosial budaya dengan menggunakan kebudayaan dari masyarakat yang bersangkutan untuk memperoleh gambaran mengenai pola-pola yang berlaku. $^{14}$

Teknik analisis data dalam penelitian ini adalah teknik analisis nonstatistik. Analisis data pada penelitian hukum ini dikerjakan dengan menggunakan logika deduksi, artinya pola berpikir dari hal-hal yang bersifat umum (premis mayor) ke hal-hal yang khusus (premis minor), untuk membangun sistem hukum positif. ${ }^{15}$

\section{B. HASIL PENELITIAN DAN PEMBAHASAN}

Hasil penelitian dan pembahasan yang saya sajikan pada kesempatan seminar hasil penelitian kali ini merupakan tinjauan pustaka yang ditulis secara ringkas, dikarenakan keterbatasan jumlah halaman yang dipersyaratkan dalam makalah seminar hasil penelitian ini.

\section{B.1. FENOMENA PELANGGARAN HAK CIPTA PROGRAM KOMPUTER DI INDONESIA}

Pada umumnya bentuk-bentuk pembajakan perangkat lunak dapat di

\footnotetext{
${ }^{14}$ Burhan, Ashshofa, Metode Penelitian Hukum, (Jakarta: Rineka Cipta, 2004), hal 20-21.

${ }^{15}$ Winarno, Surakhmad, Metode dan Tekhnik dalam bukunya, Pengantar Penelitian Ilmiah Dasar Metode Tekhnik, (Bandung: Tarsito, 1994), hal. 17.
} 
kelompok kan dalam lima kategori, yaitu: ${ }^{16}$

1) Pemuatan hard disk (Hard Disk Loading)

2) Soft lifting

3) Pemalsuan perangkat lunak (Software Counterfeiting).

4) Penyewaan perangkat lunak

5) Downloading Illegal melalui Internet

Pelanggaran Hak Cipta di bidang program komputer pada saat ini marak terjadi di Indonesia. Menurut laporan Business Software Alliance (BSA) yang dituangkan dalam global software piracy 1997, Indonesia sebagai negara ketiga yang melakukan pembajakan terbesar, yakni 93\% setelah Vietnam (99\%) dan China (96\%). Berdasarkan survey BSA di tahun 2002, Indonesia masih merupakan negara tertinggi dalam hal pembajakan perangkat lunak, sejumlah 89\% dengan nilai kerugian sebesar 70 Juta Dollar US. Pada 2005 sekira 87\% perangkat lunak yang ada di Indonesia adalah produk bajakan. Angka ini stabil sama persis seperti tahun 2004 dan turun satu digit dari tahun 2003 yang menorehkan "hasil" 88 persen. Indonesia di mata Amerika dianggap sebagai negara yang paling lemah dalam penegakan hukum (Law Enforcement) di bidang pelanggaran pembajakan program komputer.

Berdasarkan pengamatan UTR (United Trade Representative) Indonesia berada dalam kelompok negara Priority Watch list, yaitu daftar negara yang dianggap perlu diawasi karena penegakan hukumnya di anggap lemah terhadap pelanggaran Hak Milik Intelektual, dan menobatkan Indonesia sebagai nomor tiga dalam daftar "20 Country with the Highest Piracy Rates". Tepat di di bawah Vietnam dan Zimbabwe. Pada Tahun 2006 muncul laporan terbaru tentang tingkat pembajakan perangkat lunak (software). Dikarenakan tingginya pelanggaran hak cipta program komputer di Indonesia maka di harapakan open source sebagai alternatif pengurangan pelanggaran hak cipta di Indonesia.

16

Budi Santoso, Butir-Butir Berserakan Hak Atas Kekayaan Intelektual, (Bandung: CV Mandar Maju, 2005), hal. 214. 


\begin{tabular}{|c|c|c|c|c|c|c|c|c|}
\hline COUNIRY & 2005 & 2005 & 2004 & 2003 & 2006501 & 2005 SiI & 200454 & 200354 \\
\hline Australia & $2 \%$ & 25 & $22 \%$ & 35 & 5515 & का & 200 & स्या \\
\hline China & 125 & 85 & $9 \%$ & $92 \%$ & 15,09 & $528 s$ & 22565 & $\sin$ \\
\hline Hond Kong & 525 & $56 \%$ & $52 \pi$ & s2. & มอง & $\$ 112$ & 2115 & 512 \\
\hline Inda & $71 \mathrm{~s}$ & 725 & 745 & $m$ & sixs & SSSS & 5517 & 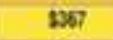 \\
\hline Indonesa & tss & Es & $\operatorname{sen}$ & as & sts & 2200 & 5125 & t19 \\
\hline Japan & 285 & $2 m$ & $2 \mathrm{k}$ & $29 \%$ & 51,701 & H., 21 & มี & t1628 \\
\hline Mabyja & $\operatorname{ses}$ & 625 & 615 & ox. & 2259 & 5169 & $\$ 134$ & $\$ 12$ \\
\hline New zearnd & 25 & $20 \%$ & $2 \pi$ & $25 \%$ & 56 & 25 & 225 & 521 \\
\hline Pakistan & Ws & s\% & 25 & ox & S16) & 49 & 28 & 516 \\
\hline Phlippines & 718 & 715 & 718 & $7 \mathrm{~s}$ & 519 & 176 & 60 & sss \\
\hline Singapre & $M$ & 205 & $\operatorname{css}$ & os, & 5125 & 285 & 86 & 50 \\
\hline South Korea & 458 & $46 \%$ & $46 \mathrm{~N}$ & $45 \%$ & Wes & 400 & 3506 & $\$ 652$ \\
\hline Taiman & 615 & as & ax & Now & tht & 5111 & $\$ 151$ & 5129 \\
\hline Thriland & ws & $\$ 5$ & $79 \%$ & SN5 & 3221 & tas & $\operatorname{sis}$ & Stat \\
\hline Vieham & ans & $90 \%$ & 928 & $92 \%$ & 596 & 288 & 258 & Ht \\
\hline Otha AP & oss & $82 \%$ & 765 & $75 \%$ & $\operatorname{lng} 2$ & 120 & 163 & 297 \\
\hline TOTALASLA & $55 \%$ & $54 \%$ & $53 \%$ & $53 \%$ & 511,396 & 58,050 & 57897 & 57555 \\
\hline
\end{tabular}

Laporan di atas menyebutkan, pada 2005 sekira 87 persen perangkat lunak yang ada di Indonesia adalah produk bajakan. Angka ini stabil sama persis seperti tahun 2004 dan turun satu digit dari tahun 2003 yang menorehkan "hasil" 88 persen. ${ }^{17}$ Yang menarik, ternyata Indonesia dan Vietnam menjadi satu-satunya wakil negara-negara ASEAN. Lebih hebat lagi, kedua wakil ini menduduki urutan pertama dan ketiga. Sebanyak 20 negara yang dianggap terbesar dalam pembajakan ini "harus" memenuhi kriteria minimal 80 persen perangkat lunak yang beredar di negaranya adalah barang bajakan.

Faktor Penyebab Banyaknya Pelanggaran Hak Cipta Program Komputer di Indonesia adalah sebagai berikut:

1) Mahalnya harga software yang asli menjadikan konsumen beralih pada software bajakan.

2) Mudahnya melakukan penyalinan pada data-data yang disimpan dalam format digital.

3) Belum meluasnya informasi mengenai kemungkinan solusi dengan memanfaatkan Open Source. Bahkan Business Software Alliance sendiri cenderung belum pernah mempromosikan Open Source sebagai langkah untuk mengurangi pembajakan di Indonesia.

${ }^{17}$ Ibid. 
4) Kemampuan daya beli rata-rata bangsa Indonesia yang masih rendah, hal ini diperparah dengan menurunnya nilai tukar rupiah terhadap dollar. Di pihak lain harga software original dalam bentuk dollar.

5) Software komputer begitu mudah di copy, bahkan dapat dilakukan oleh pendatang baru di dunia komputer.

Sebelum era Open Source dikembangkan, masyarakat tidak memiliki alternatif penggunaan software. Suatu saat jika kontrol terhadap hak kepemilikan membudaya yang disebabkan dari kesadaran pengguna ataupun adanya penegakan hukum yang ketat terhadap hak kepemilikan, maka pertimbangan komersial terhadap pemakaian program komputer menjadi penting. Calon pengguna akan mempertimbangkan secara matang dalam memilih dan menggunakan paket program komersil apabila tersedia program komputer alternatif yang bebas dimiliki dengan kemampuan yang sejenis.

\section{B.2. PERLINDUNGAN HAK CIPTA PROGRAM KOMPUTER DALAM}

\section{UNDANG-UNDANG HAK CIPTA DI INDONESIA}

Perlindungan program komputer melalui UUHC sekarang ini tidak lepas dari adanya perkembangan Hak Cipta, khususnya untuk program komputer dalam berbagai bentuk pengaturan. Konvensi Internasional yang merupakan cikal-bakal pengaturan hak milik intelektual adalah Konvensi Paris $1883^{18}$ dan Konvensi Bern tahun $1886{ }^{19}$ Konvensi Bern memberi perlindungan program komputer untuk karya literatur dan artistik. Menurut konvensi ini program komputer dilindungi sebagai karya tulisan. Digolongkannya program komputer sebagai hasil karya yang berbasis teks atau tulisan (Literary

${ }^{18}$ Paris Convention for the Protection of Industrial Property of March 20,1883. As Revised at Brussels on December 14,1900, at Washington on June 2, 1911, at The Hague on November 6, 1925, at London on June 2, 1934, at Lisbon on October 31, 1958, and at Stockholm on July 14 1967, and as Amended on September 28,1979.

${ }^{19}$ Berne Convention of September 9, 1886, terakhir direvisi di Paris on July 241971. 
Works) menurut konvensi ini karena adanya proses penulisankode-kode perintah (coding) dari programmer atau pencipta yang memerlukan penguasaan pengetahuan yang cukup dalam teknik dan bahasa pemrograman juga kesabaran dalam penulisan kode-kode tersebut, sehingga dihasilkan Source Code (kode sumber) dari program komputer yang berupa teks yang dapat dimengerti oleh orang yang mengerti bahasa pemrograman, misalnya C++, Java, Perl, PHP. Perlindungan hak cipta program komputer juga diakui berdasarkan pada WIPO Copyright Treaty terdapat pada Article 3 hingga Article 5. Pasal 10 TRIPS juga menyatakan dengan tegas mengenai perlindungan terhadap hak cipta program komputer.

Bentuk perlindungan hukum yang tersedia untuk program komputer di Indonesia selama ini masih dilakukan dengan Undang-Undang Hak Cipta. Namun demikian, melihat perkembangan negara maju lainnya tampak terjadi kecenderungan untuk memberikan perlindungan program komputer dengan hukum Paten, seperti halnya di Jepang dan Australia. Hal itu dikarenakan beberapa kelebihan yang dimiliki sistem paten di bandingkan dengan sistem hak cipta.

Perlindungan hukum yang tersedia untuk program komputer di Indonesia tercantum dalam peraturan perundang-undnagan hak cipta yang ada. Dalam UU No.6 tahun 1982 tentang Hak Cipta, program komputer belum termasuk karya cipta yang dilindungi hak cipta. Baru dengan UU No. 7 tahun 1987 tentang perubahan UU No. 6 tahun 1982 tentang Hak Cipta maka program komputer dimasukkan sebagai bagian dari karya cipta yang dilindungi dengan hak cipta di Indonesia. Perkembangan selanjutnya adalah juga dimasukkannya program komputer yang dilindungi hak cipta pada UU No.12 tahun 1997. Terakhir dengan UU No. 19 tahun 2002 tentang Hak Cipta, program komputer itu sendiri diatur pada pasal 12 UUHC yang menyatakan bahwa program komputer merupakan salah satu bentuk ciptaan yang dilindungi. 


\section{B.3. PROGRAM KOMPUTER BERBASIS OPEN SOURCE SEBAGAI ALTERNATIF PENGURANGAN PELANGGARAN HAK CIPTA PROGRAM KOMPUTER DI INDONESIA}

Terdapat dua pilihan untuk menggunakan perangkat lunak. Pertama adalah membeli proprietary software yang sudah jadi dan siap dipakai. Pilihan kedua adalah menggunakan open source software (OSS). Pilihan pertama mewajibkan pengguna untuk membayar lisensi dari perangkat lunak yang digunakan. Sementara pada pilihan kedua, open source software bersifat free.

Solusi menggunakan open source software bagi negara berkembang seperti Indonesia, seolah menjadi solusi yang mujarab. Negara Indonesia tidak ingin selalu menjadi negara dengan tingkat pembajakan perangkat lunak yang tinggi. Predikat yang buruk ini dapat merugikan Indonesia di berbagai bidang dalam kancah dunia internasional. Pemerintah Indonesia, melalui Kementerian Negara Riset dan Teknologi telah mencanangkan program IGOS (Indonesia Goes Open Source) sebagai gerakan memasyarakatkan penggunaan open source software. Penggunaan open source software dapat menekan biaya lisensi sehingga dapat mengurangi kesenjangan digital (digital divide) dengan negara-negara maju.

Kelebihan OSS (Open Source Software)

1) Biaya Investasi

(a) Biaya lisensi untuk perangkat lunak nol

(b) Perangkat keras: berbeda dengan penggunaan proprietary software, yang mensyaratkan spesifikasi perangkat keras tertentu, OSS tidak terlalu bergantung pada jenis perangkat keras tertentu. Pasalnya OSS dapat beroperasi pada PC standar dan berbagai platform perangkat keras. 
(c) Pengeluaran biaya tertuju pada perawatan (maintenance) sistem OSS.

2) Kualitas dan Kinerja

(a) Kualitas program dibuat dengan memperhatikan reliabilitas dan kinerja yang terkait dengan keseluruhan sistem yang digunakan. Dengan hasil peer review yang diperoleh dari para programmer, kualitas dan kinerja OSS dapat selalu ditingkatkan.

(b) Fleksibilitas Sistem: Perubahan requirement (baik perangkat lunak atau perangkat keras) pada OSS tidak akan terlalu berpengaruh terhadap sistem yang digunakan. Hal ini sangat berbeda dengan proprietary software, ketika requirement penyusun sistem berubah maka perangkat lunak yang digunakan harus diganti atau diperbaharui (update). Perangkat lunak yang berbasis open source lebih fleksibel digunakan tanpa terpengaruh oleh perangkat keras atau perangkat lunak lain pada sistem.

3) Keamanan

Dengan menggunakan OSS, faktor keamanan (security) selalu dapat ditingkatkan. Pasalnya, akses pada source code yang terbuka akan memudahkan pendeteksian kerusakan sistem, sehingga bisa langsung diperbaiki.

4) Lokalisasi

(a) Pengembang dapat memodifikasi program sesuai dengan kondisi dan kebutuhan masyarakat sekitar, contohnya translasi Linux ke dalam suatu bahasa tertentu.

(b) Meningkatkan kapasitas pengembang perangkat lunak lokal.

5) Independensi (kebebasan)

Berkurangnya ketergantungan terhadap suatu vendor perangkat lunak. 


\section{PENUTUP \\ C.1. Kesimpulan}

Kesimpulan yang dapat diambil dari penelitian ini adalah sebagai berikut:

1. Pelanggaran hak cipta program komputer dilakukan dengan lima kategori yaitu Pemuatan hard disk (Hard Disk Loading), Soft lifting, Pemalsuan perangkat lunak (Software Counterfeiting), Penyewaan perangkat lunak, dan Downloading Illegal melalui Internet.

2. Di Indonesia, program komputer termasuk dalam salah satu karya yang dilindungi dengan hak cipta. Dalam UU No.6 tahun 1982 tentang Hak Cipta, program komputer belum termasuk karya cipta yang dilindungi hak cipta. Baru dengan UU No. 7 tahun 1987 tentang perubahan UU No. 6 tahun 1982 tentang Hak Cipta maka program komputer dimasukkan sebagai bagian dari karya cipta yang dilindungi dengan hak cipta di Indonesia. Perkembangan selanjutnya adalah juga dimasukkannya program komputer yang dilindungi hak cipta pada UU No.12 tahun 1997. Terakhir dengan UU No. 19 tahun 2002 tentang Hak Cipta, program komputer itu sendiri diatur pada pasal 12 UUHC yang menyatakan bahwa program komputer merupakan salah satu bentuk ciptaan yang dilindungi.

3. Indonesia saat ini mulai disadari akan keterbatasan ketersediaan dana untuk pembelian perangkat lunak, maka dengan menggunakan open source hak ekonomi dari pemegang Hak Cipta telah dilepas dari semula, sehingga setiap pengguna dapat dengan bebas untuk memperbanyak, mendistribusikan ulang, menyewakan bahkan merubah atau menambah Source Code dari suatu program, jadi biaya lisensi dapat dikatakan menjadi nol rupiah. Hal ini merupakan suatu terobosan cemerlang khususnya untuk kondisi Indonesia saat ini tingginya tingkat pelanggaran hak cipta program komputer. 


\section{C.2. Saran}

Saran yang dapat diambil dari penelitian ini adalah sebagai berikut:

1. Sosialisasi terhadap penggunaan software open source yang relatif masih baru ini sehingga masyarakat pengguna software dapat mengetahui adanya software alternatif yang aman digunakan dan mudah untuk dioperasikan. Aman artinya software yang digunakan tersebut tidak melanggar hukum dan mudah dioperasikan artinya pengoperasiannya tidak jauh berbeda dengan sistem operasi yang sekarang ada.

2. Penggunaan software open source dapat dioptimalkan pemanfaatannya karena berbagai potensi dan keunggulan yang dimilikinya, sehingga dapat digunakan dalam berbagai bidang. Pemanfaatan ini misalnya di bidang pendidikan yang umumnya kekurangan biaya untuk membeli infrastruktur yang berkaitan dengan teknologi. 


\section{DAFTAR PUSTAKA}

\section{A. Buku-buku :}

Amiruddin dan Asikin, Zainal, Pengantar Metode Penelitian Hukum, (Jakarta: PT Raja Grafindo Persada, 2005).

Ashshofa, Burhan, Metode Penelitian Hukum, (Jakarta: Rineka Cipta, 2004).

F, Luthfi, Kamus Istilah Komputer dan Internet, (Yogyakarta: Pena Media, 2005).

Santoso, Budi, Butir-Butir Berserakan Hak Atas Kekayaan Intelektual, (Bandung: CV Mandar Maju, 2005).

Soekanto, Soerjono, dan Sri, Mamudji, Penelitian Hukum Normatif, (Jakarta: PT Raja Grafindo Persada, 2004).

Surakhmad, Winarno, Metode dan Tekhnik dalam bukunya, Pengantar Penelitian Ilmiah Dasar Metode Tekhnik, (Bandung: Tarsito, 1994).

B. Makalah :

Kesowo, Bambang, Pengantar Umum Mengenai Hak Atas Kekayaan Intelektual (HAKI) di Indonesia, Makalah yang disajikan pada Penataran Dosen Hukum Dagang se-Indonesia, (Yogyakarta: Fakultas Hukum Universitas Gadjah Mada, 1995).

Noor Mout, Bouwman, Perlindungan Hak Cipta Intelektual, Suatu Rintangan atau Dukungan Terhadap Perkembangan Industri, Makalah pada Seminar Hak Milik Intelektual, Kerjasama FH. USU dengan Naute van Haersolte Amsterdam, Medan Fakultas Hukum USU, tanggal 10 januari 1989. 
C. Disertasi, Jurnal, dan Koran :

Santoso, Budi, Dekonstruksi Hak Cipta, Studi Evaluasi Konsep Pengakuan Hak dalam Hak Cipta di Indonesia, Disertasi, (Semarang: Program Doktor Ilmu Hukum, Universitas Diponegoro, 2006).

Santoso, Budi, Tren Pandangan Terhadap Hak Cipta, (Semarang: Majalah Masalah- Masalah Hukum FH UNDIP, Vol. 34 No. 2 April - Juni 2006).

D. Website :

www.kcm.com, Kompas Cyber Media, Pembajakan Software Memprihatinkan, 2007.

E. Peraturan Perundangan-undangan :

Berne Convention of September 9, 1886, terakhir direvisi di Paris on July 24 1971. Paris Convention for The Protection of Industrial Property 1967.

Paris Convention for the Protection of Industrial Property of March 20,1883. As Revised at Brussels on December 14,1900, at Washington on June 2, 1911, at The Hague on November 6, 1925, at London on June 2, 1934, at Lisbon on October 31, 1958, and at Stockholm on July 14 1967, and as Amended on September 28,1979.

WIPO, Bab II bagian B1 